\title{
DIVINE IMAGES AND PRESENCES IN THE INTERTESTAMENTAL APOCRYPHA
}

Remus ONIŞOR*

\begin{abstract}
Apocrypha are written works with a biblical theme, that are either related to the Old Testament (Pseudepigrapha), or the New Testament (Christian Apocrypha), and are not part of the canonical holy books. The Holy Fathers and the ecclesiastical writers consider these works, to be of a religious nature, as well as being of doubtful origin and containing both true and false teachings.

The Apocrypha are especially important in the study of Judaism from the period of the Second Temple, and also for understanding Christianity from its beginning. These books have enjoyed great popularity among both Jews and Christians.

In ancient Judaism there is a certain tension regarding the conception of Divinity. On one hand God lives in Heaven, far away from humans, but on the other hand $\mathrm{He}$ intervenes in the world directly or through intermediaries (in his different forms or through angels). The opinions of theologians on the canonical text of the Genesis 18 (The Mamvri Epiphany) are divided: some see it as a theophany and others as an angelophany.
\end{abstract}

Apart from the pre-exile biblical literature, where we can find a series of theophanies (particularly the one from Sinai), we also have the "intertestamentary" literature where there are mentions of other theophanies or apocalyptical visions in which divine images appear.

Even when God communicates His presence to an elected person (Enoch, Esdras, Baruch etc.) we can speak of some form of divine presence. In addition, the presence or the image of divinity can be represented by an angel, and when God doesn't show Himself to man directly, descending to Earth, He elevates the man to Heaven showing his glory and majesty. So, we are still talking about a Divine presence. Even the promise of salvation indicates a visible presence of God, Jerusalem and Zion being

* PhD, Rev., Associate Professor, Faculty of Theology, "1 Decembrie 1918" University, Alba Iulia, Romania. 
often referred to as His home. Last but not least, we have in the Apocrypha the image of the Divinity as a messianic figure.

Keywords: image, divine presence, theophany, Apocrypha, angelophany

\section{Preliminaries}

There is a basic ecumenism of people having different faiths, who worship the one and true God through various religious systems. The situation changes when it comes to the multitude of teachings concerning His image and presence in the world. In the Jewish tradition, among the names given to God is included that of "the Eternal One", which refers to God's special presence in all the epochs of history.

The Christian teaching adds to the name "the Eternal One" the idea that $\mathrm{He}$ is transparent and present, in a unique way, in Jesus Christ. We can find a series of representations about God in the intertestamental apocryphal writings ${ }^{1}$.

\section{The angels as representatives of Divinity}

\section{Angelophanies}

God reveals Himself to people through the angels. Even if this way of manifestation is sometimes indirect and other times incomplete, it always involves a divine presence ${ }^{2}$. The angel, as representative of God, appears, in different contexts, in the intertestamental literature, particularly that of apocalyptic origin ${ }^{3}$.

${ }^{1}$ We have several collections of apocryphal writings. We mention here only a few.: R.H. CHARLes, The Apocrypha and Pseudoepigrapha of the Old Testament in English, Oxford, Clarendon Press, 1913; J.H. CHARLESwORTH, The Old Testament Pseudepigrapha, Garden City, Dobleday, 1983-1985; André DuPONT-SOMMER and Mark PHILONENKo (eds.), La Bible. Écrits intertestamentaires, Paris, Gallimard, 1987; Paulo SACCHI, Les apocryphes de l'Ancien Testament, Paris, Cerf, 2011; M.E. STONE, Jewish writings of the Second Temple Period, Assen, Van Gorcum, Philadephia, Fortress Press, 1984; H.F.D. SPARKS, The Apocriphal Old Testament, Oxford University Press, 1984.

2 Anders HultGARD, "Théophanie et présence divine dans le judaïsme antique: Quelques remarques á partir des textes intertestamentaires", in La littérature intertestamentaire, Colloque de Strasbourg (17-19 octobre 1983), Paris, Presses Universitaires de France, 1985, p. 43.

${ }^{3}$ Mark Philonenko, "La littérature intertestamentaire et le Nouveau Testament", in Revue 
An individual angelophany, which appears in a non-apocalyptic context, is to be found in Joseph and Aseneth $(14,1-8)^{4}$. The angel appears here as a morning star. Aseneth exclaims: "The Lord God has indeed heard me, for this star is a messenger and herald of the light of the great day. (Joseph and Aseneth 14, 2) ${ }^{5}$. The star-angel is a special messenger of the Lord, and his appearance is that of a being full of light (Joseph and Aseneth 14,9: "But his face was like lightning, and his eyes were like the light of the sun, and the hairs of his head like flames of fire, and his hands and feet like iron from the fire") 6 . The name given to the angel, that of "chief captain of all the host of the Most High" (Joseph and Aseneth 14, 7) made the theologians identify this archistrategus with Archangel Michael ${ }^{7}$ and see in it the heavenly archetype of Joseph ${ }^{8}$. The angel goes to Joseph (Joseph and Aseneth 15,9) in order to intercede his meeting with the beloved of his heart. Meanwhile, Aseneth proves to be a good hostess, offering a feast to the heavenly messenger, as Abraham treated the heavenly messengers in former times at Mamre, with "a piece of bread...a good wine of the finest flavor" $(15,14)$ and with a "honeycomb (whose smell) ...was like the breath of life $(16,4)^{9}$.

des Sciences religeuses, 47/1973, p. 271 u.

${ }^{4}$ The text of this writing was published for the first time in Romanian in 1922 by Constantin Bobulescu after a copy of a manuscript in 1753, under the title Istoria preafrumosului Iosif și a preafrumoasei Asineta (The story of the most handsome Joseph and of the most beautiful Aseneth). A newer edition with notes and presentations is to be found in Trei apocrife ale Vechiului Testament (Three Apocrypha of the Old Testament) by Cristian Bădiliță, published by Polirom Publishing House in Iași, 2000, p. 25-70. As for the importance of this legend in the Romanian area see Nicolae Cartojan, Cărțile populare in literatura românească (Folk Books in Romanian Literature), București, Enciclopedică Română Publishing House, vol. II, p. 74-78.

${ }^{5}$ I used the translation of Cristian BĂDILIȚA (ed.), "Iosif și Aseneth"(Joseph and Aseneth) in Trei apocrife ale Vechiului Testament (Three Apocrypha of the Old Testament), p. 42.

${ }^{6}$ Ibidem, p. 43.

${ }^{7}$ Mark PHILONEnKo, "Initiation et mistère dans Joseph et Aséneth" in Claas Jouco BLEEKER (ed.), Initiation: contributions to the theme of the study-conference of the International association for the history of religions held at Strasburg, September $17^{\text {th }}$ to $22^{\text {nd }} 1964$, Leiden, 1965, p. 149 u.

${ }^{8}$ Ibidem, p. 151.

${ }^{9}$ Honey is the food of ascetics, and white honey is the food of angels, equalling heavenly manna which Israel received in the desert, as gift of the Lord (see "Iosif și Aseneth" in Trei apocrife ale Vechiului Testament (Three Apocrypha of the Old Testament), p. 46) 
We also have appearances of some heavenly beings in 2 Maccabees $3,13-34$, where the angel of terror comes riding a horse, having in front of him "two other young men... notable in strength, excellent in beauty, and comely in apparel" $(3,25-26)^{10}$. In 3 Maccabees $(6,18-21)$, "the most glorious, all-powerful and true God showed forth His holy countenance" and opened the gates of heaven "from whence two angels, dreadful of form, came down" in order to help the Jews in Alexandria, who were in much trouble ${ }^{11}$.

\section{Presences and images of Divinity}

a) God close to man

In the Jewish exhortations sometimes there appear formulas that express the idea of a divine presence in man or close to man.

In the Testaments of the twelve Patriarchs ${ }^{12}$ there are a few examples. In the Testament of Issachar, when he mentions his purity $(7,1-6)^{13}$, the Patriarch urges his successors: "So do you also these things, my children, and every spirit of Beliar shall flee from you... Since you have with you the God of heaven and earth (And) walk with men in singleness of heart" $(7,7)^{14}$. This affirmation is based on the conviction of a divine presence near the righteous man. In this sense, we have another testimony in the Testament of Dan $(5,2)^{15}$, where we are told that "the God of peace" will be with the righteous.

In the Testament of Joseph $(10,2-3)^{16}$ and in the Testament of Benjamin $(6,3)^{17}$ the author underlines that "if ye follow chastity and purity with patience and prayer, with fasting in humility of heart, the Lord will dwell

${ }^{10}$ Paul ABADIE, Lecture de livres des Maccabées. Etude historique et litéraire sur la crise maccabéene, Lyon, Profac, 1996.

11 J. MÉLĖZE ModrZeJewski, Troisième Livre des Maccabèes (Bible d'Alexandrie 15.3) Paris 2008.

${ }^{12}$ Remus OnIȘOR, Testamentele celor doisprezece Patriarhi (The Testaments of the Twelve Patriarchs), Alba Iulia, Reîntregirea, 2001.

${ }^{13}$ Ibidem, p. 104.

${ }^{14}$ Ibidem, p. 104-105.

15 Ibidem, p. 120.

${ }^{16}$ Ibidem, p. 159.

${ }^{17}$ Ibidem, p. 174. 
among you" 18 . The divine presence manifests in the case of the good man, and Joseph is shown to us as a model in this respect.

The testimonies on the divine manifestations we find in the context of Jewish exhortations remind, through the way in which they are presented, of another important vetero-testamentary teaching, shekinah ${ }^{19}$. This teaching goes to the epoch of the second Temple. The first testimonies are found in the Targum of Onkelos $^{20}$, which introduces the notion of shekinah in the passages of the Pentateuch which describe God's appearance.

God's presence is revealed to the world under the form of a divine light. The Jewish wise men mention the wings of shekinah, which protect the faithful, whereas pride and sin make man draw away from "the feet of shekina" 21 . The term often appears with the purpose of emphasizing the close connection between God and Israel. The Prophet Ezekiel relates about the departure of the Glory of God (shekinah) from Jerusalem to Babylon (Ezek. $10,18-19 ; 11,22-23)$, then about its return, again, to Jerusalem (Ezek. 43, 2$5)^{22}$.

Although it personifies Shekinah, rabbinic literature makes no distinction between it and God. In the Midrashic literature, Shekinah sometimes appears in parallel with God, which might generate the idea of its separation from divinity. In the Jewish medieval philosophy Shekinah appears as freestanding ${ }^{23}$.

18 The Testament of Joseph, 10,2: "So ye too, if ye follow after chastity and purity with patience and prayer, with fasting in humility of heart, the Lord will dwell among you, because He loveth chastity" (Ibidem p. 159).

19 This Jewish word means $d$ welling-place; it derives from the same root as the word that means tabernacle, that is, temporary dwelling-place - tabernacle - of God. In Judaism it is used as a reference to the divine presence (see John ScotT, Un dicționar al Bibliei (A Dictionary of the Bible), București, Lider, 2010, p. 557).

20 The Targums are old Aramaic translations of the Bible. The one in Onkelos (second century AD) comprisesthe Pentateuch; see Dicționar Enciclopedic de Iudaism, p. 800.

${ }^{21}$ Ibidem, p. 769

22 J.-M. AAuWERS AND A. WÈnIN (ed.), Lectures et relectures de la Bible. Festschrift P.-M. Bogaert (BEThL 144), Leuven, University Press, 1999, p. $101 \mathrm{u}$.

23 The Great Rabbi Moses Maimonides (1138-1204) describes the kavod (the term equivalent to shekinah) as "the created light that God casts miraculously over one place for His glory". And again Maimonides says that in the visions and the revelations of prophets what is shown is shekinah and never God Himself (Ibidem). 
b) The theophanies

However, the way in which God makes Himself known in person and in a visible way belongs to the proper theophany. Through theophany we understand an appearance and an arrival of Divinity. It can be temporary or definitive $\mathrm{e}^{24}$.

The Biblical literature before the exile offers numerous examples of theophanies (Isaiah 2, 10-22; 13, 4-11; 66,15; Sophony 1, 12-18; Zechariah 14, 1-11; Habakkuk 3, 3-15, Psalm 49, 3-7, Genesis, 3,8, Exodus 19, 9-25; 1 Samuel 3,10). These theophanies were part of the history of ancient Judaism and constitute important parts of the sacred tradition.

The theophany in Exodus 19-24, where God reveals Himself to Moses on Mount Sinai ${ }^{25}$, has a particular value in Jewish spirituality, because that was the place where the Torah was given and received. The theophany on Sinai thus becomes object of theological reflection over the centuries, either extending the biblical account or presenting it in ways that go beyond the original frame ${ }^{26}$.

Philo of Alexandria ${ }^{27}$ affirms that the theophany on Sinai has a special significance, not only for Israel, but for the entire world.

The apocryphal writing "Biblical antiquities"28 $(11,4-5)^{29}$ presents the theophany on Sinai as an exceptional manifestation, description which we do not find in the canonical Book of Exodus. The version given by the fourth book of Ezra $^{30}(3,18-19)^{31}$ presents the same cosmic characteristics ${ }^{32}$.

${ }^{24}$ We are not discussing here the issue- theophany or angelophany ?- at the oak in Mamre or other appearances of the Lord with very general character.

25 See E. BluM, "Israël à la montagne de Dieu", in A. de PURY and T. RÖMER (eds), Le Pentateuque en question (Le Monde de la Bible, 19) Genève, 2003 ${ }^{3}$, p. 271-295.

${ }^{26}$ Ibidem.

${ }^{27}$ In De Specialibus legibus II, 188.

${ }^{28}$ A. CAQuot and M. PhILONENKo, "Introduction générale", in DuPONT/PhILONENKo, Écrits intertestamentaires, p. CIV-CX.

29 Jean HADOT, "Livre des Antiquites bibliques", in DuPONT/PhILONENKO, Écrits intertestamentaires, p. 1263.

${ }^{30}$ DuPOnt/PhILONENKO, Écrits intertestamentaires, p. CX-CXVII.

31 P. GeOltrain, "Quatrième livre d'Edras", in DuPONT/PhILONENKo, Écrits intertestamentaires, p. 1400.

32 The authors of the study entitled La Bible. Écrits intertestamentaires (CX) consider The Book of Biblical Antiquities as the best introduction to 4 Ezra. 
The author of the Book of Jubilees ${ }^{33}$ observes from the beginning that God will reveal to Moses, on Mount Sinai, the whole story of dividing the days about the law and confession $(1,4)^{34}$. The rigid interpretation of the Torah (the law) and the specific calendar in the sacerdotal milieu we find in the Jubilees is legitimate. Concrete traces of the divine manifestation, similar to the biblical theophanies have been obscured or even suppressed in the religious texts in the Hellenistic or Roman epochs. Describing the revelation on Sinai, Flavius Josephus affirms that the thunders and lightning indicate the arrival of $\operatorname{God}^{35}$.

The Book of Jubilees avoids mentioning a descent of God in person on the mountain. It only affirms that "the glory of God dwelled on Mount Sinai" $(1,2)^{36}$ and that it looked like a burning fire. This formulation is inspired from chapter 24 (15-18) of the Exodus, where God in person is replaced with the term kavod $^{37}$ and the author of the Jubilees probably preferred it out of theological reasons.

Philo of Alexandria asserts that God - the Being Himself - does not move, but "the glory of God" is the one that "descends". It thus discovers the presence of the power of God and has the purpose of strengthening the faith of the ones that will receive the Law. Nevertheless, we cannot exclude the fact that "the divine place" is completely inaccessible to $\operatorname{man}^{38}$.

According to Saint Gregory of Nyssa, during the dialogue with God, Moses exceeded the earthly condition, in order to become partaker of the eternal life ${ }^{39}$.

In 4 Ezra $(3,18)^{40}$ we are presented the appearance of God as follows:

${ }^{33}$ An Apocryphal writing in the $2^{\text {nd }}$ century BC, known also as the Little Genesis.

${ }^{34}$ A. CAQuOT, "Jubilés", in Dupont/PhILONENKO, Écrits intertestamentaires, p. 636.

${ }^{35}$ Flavius JosePHus, Antichități iudaice (Jewish Antiquities), I, III, V, 2, București, Hasefer, 1999, p. 139.

${ }^{36}$ DUPONT/PHILONENKO, Écrits intertestamentaires, p. 636.

37"Kavod"- in Greek "doxa", and in Romanian -"Slava". The term designates the manifestation of divine grandeur that is shown to the chosen people as a burning fire on Mount of Sinai. The same glory fills the Temple of Solomon (1 Kings 8-10) and this gloryis seen by Ezekiel leaving Jerusalem on the eve of itd destruction (11, 22-23).

38 *** Septuagint 1, Iași, Polirom, 2004, p. 254.

${ }^{39}$ St. GREGORY OF NYSSA, Scrieri (Writings), col. PSB, 29, București, Institutul Biblic și de Misiune al Bisericii Ortodoxe Române, 1982, p. 72-73.

${ }^{40}$ An apocryphal text written at the end of the first century AD of the Christian era (La Bible. 
"And your splendor passed through the four gates of fire and of earthquake and of wind and of ice, to give the Torah to the seed of Jacob, and your commandment to the posterity of Israel" 41 .

The way in which the sons of Israel received the Law is described similarly in the book of "Biblical antiquities" $(11,5)$ : "the stars were gathered together and the angels ran before, until God established the law of an everlasting covenant with the children of Israel, and gave unto them an eternal commandment which should not pass away" ${ }^{\prime 2}$.

\section{c) Images of the theophany, others than the one in Sinai}

In the intertestamental literature, there are theophanies or fragments of theophanies, transmitted in a non-eschatological context.

In a doxological text in 4 Ezra $(8,20-23)$ we discover two types of allusive theophany: "Whose look dries up the depths, and indignation makes the mountains to melt away" 43 . The text mentioned here uses a type of theophany, in a conventional and at the same time fragmentary manner ${ }^{44}$.

The theophany in "The life of Adam and Eve in Greek" 45 (38, 3-4) has a particular character. It is God's personal appearance on earth. The Lord descends surrounded by angels, in a chariot drawn by cherubs and the winds drew Him, in order to find the body of Adam and take it to heaven ${ }^{46}$.

There are other theophany images in the apocalyptic visions and in the prophetic oracles. We have a communication of God's revelation made to a man especially chosen. It is the case of Enoch or Ezra, who rejoice the divine presence. It is true that the apocryphal text keeps a significant silence as concerns the ways of this divine presence. We often find affirmations in which we are told that the voice of God addressed to the prophet or the

Écrits intertestamentaires, Paris, Gallimard, 1987, p.CX-CXVII).

41 P. GeOltrain, "Quatrième livre d'Edras" in DuPONT/PhILONENKo, Écrits intertestamentaires, p. 1400.

${ }^{42}$ In La Bible. Écrits intertestamentaires, Paris, Gallimard, 1987, p. 1263.

${ }^{43}$ Ibidem, p. 1433.

${ }^{44}$ A. HultgarT, art. cit., p. 48.

45 An apocryphal text with Hagadic character, also known as the Apocalypse of Moses, which belongs to the end of the first century AD (See J.B. FREY, "Adam (Livres apocryphes sous son nom)" in D.B.S. vol. I, Paris, 1928, col. 102-106).

46 Daniel Bertrand, "Vie grecque d'Adam et Ėve", in Dupont/Philonenko, Écrits intertestamentaires, p. 1792. 
visionary, directly, or through an angel, without other details concerning the manner of this divine manifestation ${ }^{47}$. Many times, there is a simple formula: "I saw a vision" (2 Baruch, 53, 1) ${ }^{48}$ or "I saw another dream" (1 Enoch 85, 1; The Testament of Joseph 19, 1$)^{49}$.

The divine presence can be represented by an angel as well. In 4 Ezra, the model of the revelation is identical for the first four visions: Ezra addresses God, and the Lord sends him an angel to communicate him His will. The same occurs in the chapter called "The Book of the Watchers" (1 Enoch 36$)^{50}$ and in "The Book of the Heavenly Luminaries" (1 Enoch 72) in the Enochian corpus.

In the apocalyptic visions, God does not reveal Himself to man on earth, but raises him to heaven in order to show him His glory. The journey to heaven, the contemplation of the divine grandeur and receiving esoteric knowledge is one of the important themes of the Jewish texts in the Hellenistic and Roman epochs (according to 1 Enoch 14, 8-16; 39, 3-44; The Testament of Levi 2-3, 2 Enoch, 3-12; The Apocalypse of Abraham 18-29) ${ }^{52}$.

d) The voice or the sound of God

There are apocryphal texts where the presence of God is much more tangible. It manifests through the voice that comes from heaven. "The voice" ${ }^{\prime 53}$ can be considered as a vehicle of the divine presence, and the idea of the voice from heaven will be found again in rabbinic Judaism in the expression "bat qol".

In 4 Ezra, when an angel no longer appears in the process of conveying

47 J.-M. RosentienL, "L'apocalypse d'Elie" in Dupont/PhiLONENKo, Écrits intertestamentaires, p. 1799 u.

48 Jean HADOT, "Apocalypse syriaque de Baruch", in Dupont/Philonenko, Écrits intertestamentaires, p. 1526.

${ }^{49}$ Remus ONIȘOR, Cartea lui Enoh și apocaliptica intertestamentară (The Book of Enoch and the Intertestamental Apocalypse), Alba-Iulia, Reîntregirea, 2000, p. 348.

${ }^{50}$ Ibidem, p. 91-94.

${ }^{51}$ Ibidem, p. 323-344.

52 J. SCHWARTZ, "Le voyage au ciel dans la littérature apocalyptique", in L'Apocalyptique, Paris, 1977, p. 91-126.

${ }^{53}$ Saint Maximus The Confessor (Philokalia, vol. III, București, Institutul Biblic şi de Misiune al Bisericii Ortodoxe Române, 2009, p. 158) says that 'the voice' is the Word... or it can be 'the movement of the conscience at every mistake, which shouts in the heart preparing the way of the Lord'. 
the divine will, God Himself manifests through his "voice". In 6, 17 we are told that Ezra hears a voice that speaks, and the sound was like that of many waters $^{54}$. The "voice" prophesies that the Lord will come in the time hereafter. The seventh and the last vision ${ }^{55}$ of Ezra starts with a revelation of the "voice" that speaks out of a bush $\left(4\right.$ Ezra 14, 2) ${ }^{56}$.

In the Syriac Apocalypse of Baruch (or 2 Baruch), the concrete role of God in conveying the divine message is not less explicit. We find twice the affirmation in which we are related that a voice from above comes to Baruch $(13,1-22,1)^{57}$. The author of the book leaves us in a particular uncertainty, as we do not know precisely who "speaks"- God or the angel Uriel.

The Apocalypse of Abraham $(8,1)^{58}$ describes a manifestation of the divine voice that underlines its character of hypostasis: "And it came to pass as I was thinking things like these with regard to my father Terah in the court of my house, the voice of the Mighty One came down from the heavens in a stream of fire, saying and calling, "Abraham, Abraham!"59 . Next $(8,5)$, we are told how "the sound of a great thunder came and burned him and his house and everything in his house" 60 .

In Paralipomena of Jeremiah ${ }^{61}$, the divine manifestation towards the prophet is presented in a curious way. In the introduction $(1,1)$ we are told in a quite simple way that God was talking to Jeremiah ${ }^{62}$. Then, the divine message continues (v. 2-10) and in verse 11 we are told that: "Upon saying

${ }^{54}$ DuPONT/PhILONENKO, Écrits intertestamentaires, p. 1414.

55 M. PhilonenKo, "La sixième Vision de IV Esdras" in L'Apocalyptique, Paris, 1977, p. 122-135.

${ }^{56}$ Ezra receives the revelation while he was staying under the oak (4 Ezra, 14, 1); this tree is considered as a privileged place for the revelation, just like Abraham's oak in Mamre (See La Bible. Écrits intertestamentaires, Paris, Gallimard, 1987, p. 1460).

57 Jean HADOT, "Apocalypse syriaque de Baruch", in DuPONT/PhILONENKO, Écrits intertestamentaires, p. 1490 and 1500.

58 Remus OnIŞOR, Două apocrife intertestamentare (Two Intertestamental Apocrypha), Alba-Iulia, Reîntregirea, 2004, p. 66.

${ }^{59}$ Ibidem, p. 78.

${ }^{60}$ Ibidem, p. 79

61 J. RiAud, "Paralipomènes de Jérémie", in DuPONT/PhILONENKo, Écrits intertestamentaires, p. $1733 \mathrm{u}$.

62 Ibidem, p. 1739. 
these, the Lord left Jeremiah" ${ }^{\prime 3}$. We see how the divine presence is clearly underlined only for the moment when the Lord leaves. Again, in chapter 3, 16 we are told that: "He (the Lord) left, as He said" ${ }^{64}$. This formula obviously implies a descent of God on earth, in a real theophany. Why doesn't the author mention this directly? Perhaps in the context of the epoch there was the tendency to avoid indicating a concrete theophany ${ }^{65}$. Here we notice a certain hesitation in materializing the divine presence and an avoidance in front of a real theophany.

e) Images of the divine presence in the eschatological thinking

Most of the eschatological pericopes in the intertestamental literature do not refer to God's appearance and this is because the eschatological episodes are God's work and He takes part concretely in the events.

A text such as the one in the Testament of Levi $4,1^{66}$, which puts forward the unfolding of a theophany in biblical style, makes no mention of God's personal arrival ${ }^{67}$. The expressions used to designate the divine presence show that it is a personal coming of the Lord. The theophany in 1 Enoch 1, 3b-8, introduce to us the Holy and Almighty coming out of his heavenly dwelling-place and descending on earth, on Mount Sinai ${ }^{68}$. He will reveal Himself surrounded by His heavenly host.

An eschatological passage in "The Dream-Visions" (1 Enoch 90, 1538) ${ }^{69}$ describes the arrival of the Lord in realistic terms: "the Lord of the sheep" comes, the earth trembles and everything sinks into the earth and the enemies of Israel will be swallowed. God will sit on a throne which will be set up "in a pleasant land", that is, the Holy Land.

Chapter 10 of the Testament of Moses ${ }^{70}$ also belongs to the group of

${ }^{63}$ Ibidem, p. 1741.

${ }^{64}$ Ibidem, p. 1745.

${ }^{65}$ A. HULTGART, art. cit., p. 50.

${ }^{66}$ Remus OnIșOR, Testamentele celor doisprezece Patriarhi (The Testaments of the Twelve Patriarchs), Alba-Iulia, Reîntregirea, 2001, p. 54.

${ }^{67}$ A. HULtGaRT, art. cit. p. 50.

${ }^{68}$ L. HARTMAN, Asking for a Meaning, a study of I Enoch 1-5, Lund: Gleerup, 1979, p. 42-44.

${ }^{69}$ Remus ONIșOR, Cartea lui Enoh și apocaliptica intertestamentară (The Book of Enoch and the Intertestamental Apocalypse), Alba-Iulia, Reîntregirea, 2000, p. 366-369.

70 Ernest-Marie Laperrousaz, "Testament de Moïse", in Dupont/Philonenko, Écrits intertestamentaires p. 995-1116 
writings that present the future theophanies ${ }^{71}$. God rises from his throne and goes out of His heavenly dwelling-place, meanwhile, various cosmic cataclysms occur $(10,4-6)^{72}$. The text of the book highlights that God reveals Himself to the peoples $(10,7)^{73}$.

God's personal appearance also characterizes 1 Enoch $25,3^{74}$, passage which reminds of the aforementioned theophanies, only that it modifies the form of the judgment. It is clear that the texts presented extend the image of the biblical theophanies, especially regarding the Lord's day, in which the image or face of God is that of judge who punishes the sinners and rewards the virtuous.

\section{f) Jerusalem as image of the divine dwelling-place}

The promise of salvation, which indicates the visible presence of Divinity, forms a distinct group of passages in the apocryphal literature. We are often told that the Lord will live in the midst of Israel, among people. Jerusalem and Sion are most often mentioned as His dwelling-place ${ }^{75}$.

In the Book of Jubilees $(1,8-18)^{76}$ it is stated that the Lord will raise His sanctuary in the midst of Israel, in order to live with His people(v.17) ${ }^{77}$. This formula is not necessarily a retrospective one, but rather allusive to a future presence of the Lord in His temple. The Book of Jubilees 1, 26 offers a definitive theophany: "until I will descend to live with you for eternity"

The idea of the future appearance of the Lord in the temple of Jerusalem is clearly stated in Jubilees 1, 28: "And the Lord revealed Himself to the eyes of all and the whole world knew that I am the God of Israel and the father of the sons of Jacob and king on Mount Sion for eternity" ${ }^{\text {"79 }}$. In the

${ }^{71}$ Ibidem.

${ }^{72}$ Ibidem.

${ }^{73}$ Ibidem.

${ }^{74}$ Remus ONIȘOR, Cartea lui Enoh și apocaliptica intertestamentară (The Book of Enoch and the Intertestamental Apocalypse), Alba-Iulia, Reîntregirea, 2000, p. 269.

${ }^{75}$ A. HULTGART, art. cit., p. 52.

${ }^{76}$ Dupont/PhiLONENKo, Ecrits intertestamentaires, p. 637-638.

77 The building of a temple by the Lord Himself is also mentioned in the Temple Scroll (29,

7-10) and in 1 Enoh 90, 29 (see La Bible. Écrits intertestamentaires, Paris, Gallimard, 1987, p. 88).

${ }^{78}$ Dupont/Philonenko, Écrits intertestamentaire, p. 640.

${ }^{79}$ Ibidem. 
Testament of Levi $(5,2)$, God promises the patriarch the blessings of priesthood: "until I come and sojourn in the midst of Israel" Testaments of the Twelve Patriarchs contain a series of passages which mention the coming of God in person, in the eschatological era (The Testament of Simeon 6, 5; The Testament of Judah 22, 2; The Testament of Naphtali 8,3$)^{81}$. The Testament of Dan $(5,13)$ is the most intuitive: And no longer shall Jerusalem endure desolation, nor Israel be led captive; For the Lord shall be in the midst of it [living amongst men $]^{82}$. The belief that the Lord will come in the future and will dwell in the Temple of Jerusalem is also attested in the Sibylline Oracles (III, 785-787) ${ }^{83}$ : "Be of good cheer, O maiden, and be glad; for he who made the heaven and earth gave thee joy in thy age. And he will dwell in thee and thine shall be immortal" 84 .

g) The eternal light, symbol of the divine presence

The specification of this immortal light is nothing else but God's burning kavod. We have a series of apocryphal texts which make the future glory of Jerusalem and the return of the ones dispersed among people's essential themes of Jewish theology (1 Baruch 4, 30-5, 9; Psalms of Solomon 11; The Testament of Zebulun 9, 8) ${ }^{85}$.

The appearance of the Lord is connected in these texts to the idea of God's bright kavod, conception which implies a less personal and less tangible presence. The use of the notion of kavod as an expression of God's eschatological presence is to be found especially in the texts at Qumran (the Damascus Document XX, 25-26 ${ }^{86}$; the War Rule I, 8-9 ${ }^{87}$ ). These passages do not contain the theme of the joy of Jerusalem and of the return of the

${ }^{80}$ Remus ONIȘOR, Testamentele celor doisprezece Patriarhi Patriarhi (The Testaments of the Twelve Patriarchs), Alba-Iulia, Reîntregirea, 2001, p. 56.

${ }^{81}$ Ibidem, p. 45, 92, 133.

${ }^{82}$ Ibidem, p. 122.

83 Valentin NikiprowetzKY, "Oracles Sibyllins", in DuPONT/PhILONENKo, Écrits intertestamentaires, p. 1019-1140.

${ }^{84}$ Ibidem, p. 1094.

${ }^{85}$ Dicționar Enciclopedic de Iudaism, p. 808-812.

86 André DupONT-SOMMER, "Écrit de Damas", in DuPONT/PHILONENKO, Écrits intertestamentaires, Paris, Gallimard, 1987, p. 135-183.

${ }^{87}$ IDEM, "Réglement de la Guerre", in DuPONT/PHILONENKO, Écrits intertestamentaires, p. 187-226. 
enslaved people.

\section{Conclusions}

In the apocryphal intertestamental texts there appear a series of faces and images representing God's presence in the midst or with His people. We also notice that there is no Messianic figure next to God, in the manifestation of His presence.

If we take into account a few specifically Messianic texts, such as the Psalms of Solomon 17-18, or the Parables of Enoch (1 Enoch 38-71), here we do not find an eschatological presence of God in person. God's appearance is here replaced by the manifestation of a Messiah. And conversely, in the cases where God's coming on earth is announced, the texts do not contain an expectation or a presence of Messiah (1 Enoch 1-36; the Book of Jubilees; the Testament of Moses).

There are also apocryphal writings - the Testaments of the Twelve Patriarchs, the Dream-Visions (1 Enoch 83-90), the third book of the Sibylline Oracles), which contain, on the one hand, the coming of a Messianic figure, and on the other hand, even the Lord God in person.

These faces and images of the divine presence in the earthly world have had a considerable influence on the Christian teachings that developed subsequently in the Church. It is true that here, in the Church, the richness of the divine representations is so great that it requires a multidisciplinary approach.

\section{References:}

1. *** Septuaginta, vol. 1, Iași, Polirom, 2004.

2. BĂDILIȚĂ, Cristian, Trei apocrife ale Vechiului Testament (Three Apocrypha of the Old Testament), Iași, Polirom, 2000.

3. BERTRAND, Daniel, "Vie grecque d'Adam et Ėve", in André DupontSommer and Mark Philonenko (editors), La Bible. Écrits intertestamentaires, Paris, Gallimard, 1987.

4. CAQUOT, A., ,Jubilés”, in André Dupont-Sommer and Mark Philonenko (eds.), La Bible. Écrits intertestamentaires, Paris, Gallimard, 1987.

5. Caquot, A./ PhilonenKo, M., "Introduction générale", in André DupontSommer and Mark Philonenko (editors), La Bible. Écrits intertestamentaires, Paris, Gallimard, 1987.

6. CARTOJAN, Nicolae, Cărțile populare în literatura românească (Folk 
Books in Romanian Literature), București, Enciclopedică Română Publishing House, vol. II.

7. FREY, J.B., “Apocryphes de l'Ancien Testament", in Supplement au Dictionnaire de la Bible (then: D.B.S.), Tomme I, Paris, 1928.

8. Geoltrain, P., "Quatrième livre d'Edras", in André Dupont-Sommer and Mark Philonenko (editors), La Bible. Écrits intertestamentaires, Paris, Gallimard, 1987.

9. HADOT, Jean, "Apocalypse syriaque de Baruch", in André DupontSommer and Mark Philonenko (editors), La Bible. Écrits intertestamentaires, Paris, Gallimard, 1987.

10. HADOT, Jean, "Livre des Antiquites bibliques", in André Dupont-Sommer and Mark Philonenko (editors), La Bible. Écrits intertestamentaires, Paris, Gallimard, 1987.

11. Hultgard, Anders "Théophanie et présence divine dans le judaïsme antique: Quelques remarques á partir des textes ,intertestamentaires"', in La littérature intertestamentaire, Colloque de Strasbourg (17-19 octobre 1983), Paris, Presses Universitaires de France, 1985.

12. ONIȘOR, Remus, Cartea lui Enoh și apocaliptica intertestamentară (The Book of Enoch and the Intertestamental Apocalypse), Alba-Iulia, Reîntregirea, 2000.

13. ONIȘOR, Remus, Două apocrife intertestamentare (Two Intertestamental Apocrypha), Alba-Iulia, Reîntregirea, 2004.

14. ONIȘOR, Remus, Testamentele celor doisprezece Patriarhi (The Testaments of the Twelve Patriarchs), Alba-Iulia, Reîntregirea, 2001.

15. PHILONENKO, Mark, "La littérature intertestamentaire et le Nouveau Testament", in Revue des Sciences religeuses, 47/1973.

16. PRAGER, Viviane (coordinator), Dicționar Enciclopedic de Iudaism (Encyclopedic Dictionary of Judaism), București, Hasefer Publishing House, 2000.

17. SACCHI, Paulo, Les apocryphes de l'Ancien Testament, Paris, Cerf, 2011.

18. SCHWARTZ, J., "Le voyage au ciel dans la littérature apocalyptique", in L'Apocalyptique, Paris, 1977. 